\title{
Molecular phylogenies confirm the presence of two cryptic Hemimycale species in the Mediterranean and reveal the polyphyly of the genera Crella and Hemimycale (Demospongiae: Poecilosclerida)
}

\author{
Maria J Uriz ${ }^{\text {Corresp., }}{ }^{1}$, Leire Garate ${ }^{1}{ }^{\text {, Gemma Agell }}{ }^{1}$ \\ ${ }^{1}$ Department of Marine Ecology, Centre for Advanced Studies of Blanes (CEAB-CSIC), Blanes, Girona, Spain \\ Corresponding Author: Maria J Uriz \\ Email address: iosune@ceab.csic.es
}

Background. Sponges are particularly prone to hide cryptic species as their paradigmatic plasticity often favors species phenotypic convergence as a result of adaptation to similar habitat conditions. Hemimycale is a sponge genus ( $F$. Hymedesmiidae, O. Poecilosclerida) with four formally described species, from which only $\mathrm{H}$. columella had been recorded in the Atlanto-Mediterranean basin, on shallow to $80 \mathrm{~m}$ deep bottoms. Contrasting biological features between shallow and deep individuals of $H$. columella suggested larger genetic differences than those expected between sponge populations. To assess whether shallow and deep populations belonged indeed into different species, we performed a phylogenetic study of $\mathrm{H}$. columella across the Mediterranean. We also included other Hemimycale and Crella species from the Red Sea, with the additional aim of clarifying the relationships of the genus Hemimycale. Methods. Hemimycale columella was sampled across the Mediterranean, and Adriatic Seas. H. arabica and Crella cyathophora were collected from the Red Sea and Pacific. From two to three specimens per species and locality were extracted, amplified for COI (M1-M6 partition), 18S rRNA, and 28S (D3-D5 partition) and sequenced. Sequences were aligned using Clustal W v.1.81. Phylogenetic trees were constructed under Neighbour Joining (NJ), Bayesian Inference (BI) and Maximum Likelihood (ML) criteria as implemented in Geneious software 9.01. Moreover, spicules of the target species were observed through Scanning Electron microscope. Results. The several phylogenetic reconstructions retrieved both Crella and Hemimycale polyphyletic. Strong differences in COI sequences indicated that Crella cyathophora from the Red Sea might belong in a different genus, closer to Hemimycale arabica than to the AtlantoMediterranean Crella spp. Molecular and external morphological differences between $H$. arabica and the Atlanto-Mediterranean Hemimycale also suggest that $H$. arabica fit in a separate genus. On the other hand, the Atlanto-Mediterranean Crellidae appeared in $18 \mathrm{~S}$ and $28 \mathrm{~S}$ phylogenies as a sister group of the Atlanto-Mediterranean Hemimycale. 
Moreover, what was known up to now as $H$. columella, is formed by two cryptic species with contrasting bathymetric distributions. Some small but consistent morphological differences allow species distinction. Conclusions. A new family (Hemimycalidae) including the genus Hemimycale and the two purported new genera receiving Crella cyathophora and $\mathrm{H}$. arabica, might be proposed according our phylogenetic results. However, the inclusion of additional OTU's appears convenient before taking definite taxonomical decisions. A new cryptic species (Hemimycale mediterranea sp. nov.) is described. Morphologically undifferentiated species with contrasting biological traits, as those here reported, confirm that unidentified cryptic species may confound ecological studies. 
1 Molecular phylogenies confirm the presence of two cryptic Hemimycale species in the

2 Mediterranean and reveal the polyphyly of the genera Crella and Hemimycale (Demospongiae:

3 Poecilosclerida) 
Results. The several phylogenetic reconstructions retrieved both Crella and Hemimycale polyphyletic. Strong differences in COI sequences indicated that Crella cyathophora from the Red Sea might belong in a different genus, closer to Hemimycale arabica than to the AtlantoMediterranean Crella spp. Molecular and external morphological differences between $H$. arabica and the Atlanto-Mediterranean Hemimycale spp. also suggest that $H$. arabica fit in a separate genus. On the other hand, the Atlanto-Mediterranean Crellidae appeared in 18S and 28S phylogenies as a sister group of the Atlanto-Mediterranean Hemimycale. Moreover, what was known up to now as H. columella, is formed by two cryptic species with contrasting bathymetric distributions. Some small but consistent morphological differences allow species distinction. Conclusions. A new family (Hemimycalidae) including the genus Hemimycale and the two purported new genera receiving Crella cyathophora and $H$. arabica, might be proposed according to our phylogenetic results. However, the inclusion of additional OTU's appears convenient before taking definite taxonomical decisions. A new cryptic species (Hemimycale mediterranea sp. nov.) is described. Morphologically undifferentiated species with contrasting biological traits, as those here reported, confirm that unidentified cryptic species may confound ecological studies.

\section{Introduction}

The discovery of cryptic species is continuously improving our knowledge on real ecosystem biodiversity and functioning, which are intimated related (Frainer, McKie \& Malmqvist, 2014). Unrecognized cryptic diversity may mask biological features such as divergent reproduction patterns, growth dynamics, and inter-species interactions, among others ( Knowlton, 1993; Prada et al., 2014; de Meester et al., 2016; Loreau, 2004), which may confound conservation studies (Forsman et al., 2010) and obscure the introduction pathway of invasive species (Knapp et al., 2015).

Molecular tools help to confirm suspected hidden species. However, molecular based identifications alone do not solve the problem of species misidentification, in particular when the cryptic species have overlapping distributions (e.g. Knowlton \& Jackson, 1994; Tarjuelo et al., 2001; De Caralt et al., 2002; Blanquer \& Uriz, 2007, 2008; Pérez-Portela et al., 2007). In these cases, deep studies on their morphology, biology (e.g. life-history traits), and ecology (e.g. 
growth dynamics) become crucial to understand the mechanisms underlying their coexistence (López-Legentil et al., 2005; Pérez-Portela et al., 2007; Blanquer, Uriz \& Agell, 2008; Payo et al., 2013).

Sponges are sessile, aquatic filter-feeders that are widespread across oceans, depths, and ecosystems (Van Soest et al., 2012), with so far 8,789 accepted species inventoried in 2016 (Van Soest et al., 2016) and ca. 29,000 predicted to be discovered in the forthcoming years (Hooper \& Lévi, 1994; Appeltans et al., 2012), many of which remain currently hidden among supposed widespread morpho-species (Uriz \& Turon, 2012).

The poor dispersal capacities of sponges prevent in most cases gene flow among populations even at short geographical distances (Boury-Esnault et al. 1993; Uriz et al., 1998; Nichols \& Barners 2005; Marinai et al. 2006; Uriz, Turon \& Mariani 2008). Consequently, sponge populations become genetically structured (Boury-Esnault et al. 1993; Duran, Pascual \& Turon, 2004; Blanquer, Uriz \& Caujapé-Castells, 2009; Guardiola, Frotscher \& Uriz, 2012, 2016), which favors speciation, while the sponge plasticity fosters phenotypic (morphological) convergence to similar habitats (Blanquer \& Uriz, 2008).

Many cryptic, new sponge species have been discovered in the last decades thanks to the use of molecular markers (see Uriz \& Turon, 2012 for a review until 2012, Knapp et al., 2015; de Paula et al., 2012). However, less often, molecularly discovered new species have also been described morphologically (but see Blanquer \& Uriz, 2008; Cárdenas \& Rapp, 2012; Reveillaud et al., 2011, 2012), which is necessary if phylogeny is aimed to translate into taxonomy, and the new species are wanted to be considered in ecological studies.

Sponge species can be both morphologically (e.g. Uriz \& Turon, 2012) and, more rarely, molecularly (with the markers used) cryptic (Carella et al., 2016; Vargas et al., 2016) but show contrasting biological features. For instance, Scopalina blanensis (Blanquer \& Uriz, 2008), which is sympatric with Scopalina lophyropoda, mainly grows in winter. Conversely, $S$. lophyropoda regresses in winter and grows principally in summer-autumn (Blanquer, Uriz \& Agell, 2008), thus indicating temporal niche partition.

The Order Poecilosclerida (Porifera: Demospongiae) harbors the highest number of species within the Class Demospongiae (Systema Porifera) and it is far from being resolved from a phylogenetic point of view (Morrow et al., 2012; Thacker et al., 2013). Within Poecilosclerida, the Family Hymedesmiidae represents a hotchpotch where genera of dubious adscription have 
been placed (Van Soest, 2002). As expected, this family appeared clearly polyphyletic in a molecular phylogeny of the so-called G4 clade based on 28S rRNA gene (Morrow et al., 2012).

Hymedesmiidae currently contains ten accepted genera among which, Hemimycale Burton, 1934 (Van Soest et al. 2016). The position of genus Hemimycale, which shares with Hymedesmia, and Phorbas (Hymedesmiidae) and with Crella (Crellidae) the so-called aerolate areas with an inhaling function, has changed from Hymeniacidonidae in Halichondrida (Lévi, 1973) to Hymedesmiidae in Poecilosclerida (Van Soest, 2002). More recently, in $18 \mathrm{~S}$ phylogenies of Poecilosclerida, Hemimycale columella was retrieved within the Crellidae clade, although with low support (Redmond et al., 2013).

Hemimycale harbors only four formally described species (Van Soest et al. 2016): the type species Hemimycale columella (Bowerbank, 1874), from Northwestern Atlantic and Mediterranean, Hemimycale rhodus (Hentchel, 1929) from the North Sea, Hemimycale arabica Illan et al., 2004 from the Red Sea and Hemimycale insularis Moraes, 2011 from Brazil. However, the simple spicule complement of the genus, which only consists of strongyles with some occasional styles, may propitiate the existence of morphologically (based on the spicules) cryptic species.

H. columella, the type species of Hemimycale, is widely distributed across the AtlantoMediterranean basin, from shallow (ca. $10 \mathrm{~m}$ ) to deep (ca. $60 \mathrm{~m}$ ) waters (Uriz, Rossell \& Martin 1992). Assays performed with eight microsatellite loci developed from deep specimens of $H$. columella (González-Ramos, Agell \& Uriz, 2015) failed to amplify a high percentage of the assayed individuals from a shallow population, which suggested larger genetic differences than those expected between intra-species sponge populations.

Furthermore, the species life cycle has been monitored in a shallow Northwestern Mediterranean population of what was though to be H. columella (Pérez-Porro, González \& Uriz, 2012), where all individuals disappeared after larval release in early November and new individuals arose the forthcoming year but on different rocky sites, which pointed to annual mortality and subsequent recruitment from sexually produced propagula (settling larvae). Conversely, during a study of deeper populations of $H$. columella (González-Ramos, Agell \& Uriz, 2015), we recorded their survival for more than three years. Thus, shallow and deep populations of $H$. columella seemed to show contrasting life spans, which were thought to be a result of contrasting habitat characteristics. However, a two-year monitoring of two, some km 
apart, populations (one deep and one shallow) and the main environmental factors at both locations, confirmed their contrasting life span and growth traits, as well as proved no correlation between biological features and environmental factors (authors unpublished data), which rather pointed to population intrinsic (genetic) differences.

To assess whether these two population types with contrasting biological traits but without clearly distinct morphological characters belonged or not to different species, we performed a phylogenetic study of individuals considered as $H$. columella across the Mediterranean, using three molecular (nuclear and mitochondrial) gene partitions. We incorporated additional species to the analyses to gain knowledge on the relationships between Hemimycale species and other genera of families Hymedesmiidae and Crellidae.

\section{Material and Methods}

\section{Sampling}

Fragments of what a priori was thought to be Hemimycale columella were collected by SCUBA diving across the Northwestern, central and eastern Mediterranean, and Adriatic Sea, between 12 and $45 \mathrm{~m}$ of depth during several campaigns (Coconet, Benthomics, and MarSymbiOmics projects) (Table 1). Moreover, fragments of Hemimycale arabica and Crella cyathophora from the Red Sea (Dedalos and Ephistone) and Pacific (Bempton Islands) between 5 and $20 \mathrm{~m}$ depth were also collected (Table 1). Individuals were photographed underwater before sampling. Collected fragments were divided into two pieces, one of them was preserved in $100 \%$ ethanol and, after three alcohol changes, kept at $-20^{\circ} \mathrm{C}$ until DNA extraction; the other fragment was fixed in 5\% formalin in seawater and preserved in $70 \%$ ethanol as a voucher for morphological and spicule studies. All vouchers have been deposited at the Sponge collection of the Centre d'Estudis Avançats de Blanes (numbers CEAB.POR.GEN.001 to CEAB.POR.GEN.029).

\section{DNA extraction, amplification, and sequencing}

DNA extractions were performed on two to three specimens per species and locality (totaling 18 individuals). Hemimycale spp. were extracted with QIAmp DNA stool kit (Qiagen), while Crella spp. were extracted with DNeasy Blood \& Tissue kit (Qiagen) according to the manufacturer's protocol. Standard primers were used for COI partitions M1-M6 (Folmer et al., 1994) and 18S rRNA (1F and 1795R, from Medlin et al., 1988), and Porifera primers for the D3-D5 partition of 
28S rRNA (Por28S-830F and Por28S-1520R, from Morrow et al., 2012). Different amplification protocols were performed for each gene (Table 2). COI (M1-M6 partition) amplifications were performed in a $50 \mu \mathrm{L}$ volume reaction, containing 37,.6 $\mu \mathrm{L} \mathrm{H}_{2} 0,5 \mu \mathrm{L}$ buffer KCL (BIORON), 2 $\mu \mathrm{L}$ BSA, $2 \mu \mathrm{L}$ dNTP (Sigma), $1 \mu 1$ of primers, $0.4 \mu \mathrm{L}$ Taq (BIORON) and $1 \mu \mathrm{L}$ of genomic DNA. $18 \mathrm{~S}$ rRNA amplifications were performed in a $50 \mu \mathrm{L}$ volume reaction, containing $36,85 \mu \mathrm{L} \mathrm{H}_{2} 0$, $5 \mu \mathrm{L}$ buffer (INVITROGEN), $0,75 \mu \mathrm{L} \mathrm{MgCl}$ (INVITROGEN), 1,2 $\mu \mathrm{L}$ DMSO (dimethyl sulfoxide), $1 \mu \mathrm{L}$ BSA, $1.5 \mu \mathrm{L}$ dNTP (Sigma), $1 \mu$ of primers, $0.7 \mu \mathrm{L}$ Taq (INVITROGEN) and 1 $\mu \mathrm{L}$ of genomic DNA. Finally, partition D3-D5 of 28S rRNA amplifications were performed in a $50 \mu \mathrm{L}$ volume reaction, containing $36.85 \mu \mathrm{L} \mathrm{H}_{2} 0,5 \mu \mathrm{L}$ buffer (INVITROGEN), $0.75 \mu \mathrm{L} \mathrm{MgCl}$ (INVITROGEN), $2 \mu \mathrm{L}$ BSA, $2 \mu \mathrm{L}$ dNTP (Sigma), $1 \mu \mathrm{l}$ of primers, $0.4 \mu \mathrm{L}$ Taq (INVITROGEN) and $1 \mu \mathrm{L}$ of genomic DNA. PCR products were purified and sequenced in both directions using Applied Biosystems 3730 xl DNA analyzers in Macrogen, Korea.

\section{Sequence alignment and phylogenetic reconstructions}

Sequences of COI, 28S, and 18S were aligned using Clustal W v.1.81, once their poriferan origin was verified using BLAST (http://blast.ncbi.nlm.nih.gov/Blast.cgi), as implemented in Genieous 9.01 (Kearse et al., 2012). When sequences were identical only one sequence per locality and species was included in the phylogenetic trees. After alignment, ambiguous regions were determined with Gblocks v.091 b software (Castresana, 2000), which removes from 1\% to $4 \%$ of poorly aligned positions and divergent regions of an alignment of DNA. Representatives of family Hymedesmiidae (i.e genera Phorbas and Hymedesmia) and Crambeidae, (i.e. genera Crambe and Monanchora) were selected as outgroups. The inclusion of Crambeidae as an outgroup was decided because the species $H$. arabica had been reported to contain similar secondary metabolites (polycyclic guanidine alkaloids) to those of Crambe and Monanchora (Ilan et al. 2004)

JModelTest 0.1.1 (Posada, 2008) was used to determine the best-fitting evolutionary model for each dataset. The model GTR $+\mathrm{I}+\mathrm{G}$ was used for both mitochondrial and nuclear genes. Phylogenetic trees were constructed under Neighbour Joining (NJ) (default parameters), Bayesian Inference (BI) and Maximum Likelihood (ML) using Geneious software 9.01 (Kearse et al., 2012). NJ generates unrooted minimum evolution trees (Gascuel \& Steel, 2006). BI analyses were performed with MrBayes 3.2.1 (Ronquist \& Huelsenbeck, 2003). Four Markov 
Chains were run with one million generations sampled every 1000 generations. The chains converged significantly and the average standard deviation of split frequencies was less than 0.01 at the end of the run. Early tree generations were discarded by default $(25 \%)$ until the probabilities reached a stable plateau (burn-in) and the remaining trees were used to generate a $50 \%$ majority-rule consensus tree. ML analyses were executed with PhyML v3.0 program (Guindon \& Gascuel, 2003; Guindon et al., 2005). The robustness of the tree clades was determined by a nonparametric bootstrap resampling with 1000 replicates in PhyML. MrBayes and PhyML were downloaded by Genieous.

Incongruence Length Difference (ILD) test (PAUP 4.0b10) was run (Swofford, 2002) to verify sequence homogeneity or incongruence between the $18 \mathrm{~S}$ rRNA and COI markers and the $18 \mathrm{~S}$ and $28 \mathrm{~S}$ rRNA markers. The ILD test indicated no significant conflict $(\mathrm{p}=0.93$ and $\mathrm{p}=0.91$, respectively) between the marker pairs to be concatenated. Thus, concatenated 18S-COI and 18S-28S rRNA datasets were constructed for the species with sequences available for both markers. The phylogeny on the three genes concatenated was not performed due to the few species/individuals for which the three genes were available.

\section{Phenotypic characters}

To assess whether molecular differences among the target populations and species (H.columella, senso latus, H. arabica, and C. cyathophora) were supported by morphological and spicule traits, the target species were observed both in situ and on recently collected samples. Moreover, spicules of all the species were observed through light and Scanning Electron Microscopes (SEM) after removing the sponge organic matter from small $\left(3 \mathrm{~mm}^{3}\right)$ pieces of each individual by boiling them in $85 \%$ Nitric acid in a Pyrex tube and then washed three times with distilled water and dehydrated with ethanol $96 \%$ (three changes). A drop of a spicule suspension in ethanol per individual was placed on $5 \mathrm{~mm}$ diameter stuffs, air dry, and gold-palladium metalized (Uriz, Turon \& Mariani, 2008) in a Sputtering Quorum Q150RS. Observation was performed through a Hitachi M-3000 Scanning Electron Microscope at the Centre d'Estudis Avançats de Blanes.

Genus name: urn:Isid:zoobank.org:act:3601D851-F9D2-4364-83F5-7A466DC432F3, Species name: urn:lsid:zoobank.org:act:2FC4AC75-2378-4FFA-801A-2A3475BFDF31, Publication 
LSID: urn:Isid:zoobank.org:pub:48910653-0343-4A8D-911F-3498A755F305 or MycoBank: http://www.mycobank.org/mb/283905.

\section{Results}

18S rRNA phylogeny

The resulting phylogeny using the 18S rRNA partition on 25 sequences (17 new) of 695 nt. (46 variable positions, from which 38 were parsimony informative) was congruent under BI, and ML and just differed in the position of H. arabica which appeared as a sister group of the remaining Crella spp and Hemimycale spp under NJ (Fig. S1). The representatives of the family Crambeidae (Monanchora) appeared as outgroups and the genus Phorbas was a sister group of the remaining species. In the BI, NJ, and ML trees, the genera Hemimycale and Crella appeared polyphyletic, with the Red Sea species Hemimycale arabica and Crella cyathophora, far away from the Atlanto-Mediterranean Hemimycale and Crella species. The Atlanto-Mediterranean Crella formed a well-supported clade (1/ 81/98, posterior probability/bootstrapping values), which was the sister group of the Atlanto-Mediterranean Hemimycale (1/97/98). Moreover, the deep Hemimycale columella clustered with an Atlantic sequence downloaded from the GeneBank (0.89/89/88) forming a separate clade from the also well-supported (1/97/98) group containing the shallow Mediterranean Hemimycale. No genetic differences for this partition were found among shallow individuals. In the BI and ML trees the two individuals of $H$. arabica appeared in unresolved positions while they formed a poorly supported $(75 \%)$ clade in the tree under the NJ criterion (not shown).

\section{$28 S$ rRNA(D3-D5) phylogeny}

The 28S rRNA (D3-D5) dataset comprised 31 sequences (24 new) of 623 nt. (84 variable positions from which, 60 parsimony infortmative)

The resulting phylogenies were congruent with the three clustering criteria and matched in most cases the phylogeny based on the 18S rRNA partition, although the supporting values of some clades were in some cases slightly lower (Fig. S2).

The three phylogenies retrieved the representatives of Family Crambeidae (Monanchora and Crambe) as outgroup. The monophyly of the in-group containing Crella spp. and 
Hemimycale spp. was strongly supported under the BI, NJ, and ML criteria (1/100/100). The genus Phorbas was a sister group of the remaining species considered. Crella was polyphyletic, with $C$. cyathophora separated from the well-supported clade (1/100/100) encompassing the Atlanto-Mediterranean Crella. The latter appeared as a sister clade of a poorly supported group (0.7/77/70) harboring C. cyathophora and Hemimycale spp. The Hemimycale spp. group, although monophyletic, was poorly supported under the NJ and ML criteria (77/70) while the Atlanto-Mediterranean Hemimycale clade was well supported under the three clustering criteria $(1 / 92 / 95)$.

The deep and shallow Mediterranean populations of Hemimycale formed two wellsupported monophyletic groups $(0.96 / 87 / 83$ and $0.96 / 100 / 98$, for deep and shallow individuals, respectively), the former containing the Atlantic sequence of $H$. columella. No genetic differences for this partition were retrieved for shallow individuals despite their spread distribution across the Mediterranean. The individuals of C. cyathophora from the Red Sea clustered with those from the Pacific collected between Australia and Nouvelle Caledonie $(1 / 89 / 76)$.

\section{COI phylogeny}

The COI dataset included 21 sequences (15 new) of $535 \mathrm{nt}$. (169 variable positions, from which 149 parsimony informative).

The COI phylogeny, which was congruent under BI, NJ, and ML, also retrieved the representatives of Crambeidae as outgroups of the group formed by Crella, Phorbas, and Hemimycale. The genus Phorbas clustered with the Atlanto-Mediterranean Crella spp. (0.98/100/86) likely because we only included one individual/species of Phorbas (Fig. S3).

A clade containing Hemimycale spp. and C. cyathophora was well supported (0.94/94/80). The Hemimycale clade was divided into two subclades corresponding to deep and shallow individuals. No genetic differences among shallow individuals were found. A sister, well supported group (1/100/94) contained C. cyathophora and H. arabica representatives with almost no genetic differences between them (Fig. S3).

\section{Concatenated trees}


The concatenated 18S+28S rRNA (Fig. 1) confirmed the outgroup position for the Crambeidae representative (Monanchora), the polyphyly of Crella with the Red Sea and Pacific species forming a separate clade (1/100/100) from the Atlanto-Mediterran Crella, which appeared in a non-resolved position. Hemimycale also appeared polyphyletic, but the position of H. arabica was unresolved. The Atlanto-Mediterranean Hemimycale clade was confirmed as well as its division into two subclades: one containing the deep Mediterranean individuals together with two Atlantic sequences of the species and the other one harboring the shallow Mediterranean individuals, which did not show any genetic difference across the Mediterranean and Adriatic Sea.

The concatenated 18S rRNA+COI (Fig. 2) tree contained only 13 sequences and no representative of Crambeidae could be included. The representatives of the AtlantoMediterranean Crella appeared as outgroups of the remaining target species, which formed two well-supported clades: one containing C. cyathophora and H. arabica representatives $(1 / 100 / 100)$ and the other with the Atlanto-Mediterranean Hemimycale $(1 / 100 / 100)$ divided in two monophyletic well-supported groups (deep and shallow individuals).

\section{Discussion}

The phylogenetic reconstructions performed with 18S, 28S rRNA and COI, as well as with concatenated genes (18S rRNA+COI and $18 \mathrm{~S}+28 \mathrm{~S}$ rRNA) support the polyphyly of Crella and Hemimycale, under the three clustering criteria used. As although Hemimycale was monophyletic with the 28S rRNA (D3-D5) marker, the clade was not statistically supported.

Crella cyathophora sequences differ from those of the Atlanto-Mediterranean Crella spp. in $2 \%$ (18S rRNA), $2.19 \%$ (28S rRNA), and $10.24 \%$ (COI). These genetic distances suggest that, despite some spicule similitude (presence of acanthoxeas and smooth diactines with Atlanto-Mediterranean Crella spp.), the former species belongs in a different genus, closer to Hemimycale arabica $(0.71 \%$ with $18 \mathrm{~S}$ rRNA, $1.37 \%$ with $28 \mathrm{~S}$ rRNA and none with COI) than to the Atlanto-Mediterranean Crella spp.

H. arabica differs from the Atlanto-Mediterranean Hemimycale spp. in 1.43-1.86\% with 18S rRNA, $1.78-2.19$ with $28 \mathrm{~S}$ rRNA, and in 8.38-8.64 \% with COI. These strong COI differences and the contrasting morphological traits (blue external color, irregular, rim-free, aerolate areas and abundance of true styles in H. arabica vs. orange-pinkish color, circular, 
rimmed aerolate areas, and slightly asymmetrical anystrongyles almost exclusively in Hemimycale spp.) also indicate that $H$. arabica would belong in a different genus, which might also include C. cyathophora, as there are not COI differences between these two species.

Moreover, the Atlanto-Mediterranean Crellidae appeared in 18S and 28S rRNA phylogenies as a sister group of the Atlanto-Mediterranean Hemimycale, which suggests higher affinities of this genus with Crellidae than with Hymedesmiidae (its current family). However, more complete analyses including additional Crellidae and Hymedesmiidae OTUs are needed to move Hemimycale from Hymedesmiidae to Crellidae.

The phylogenetic trees with any of the three gene partitions either separately or concatenated confirm the presence of two cryptic Hemimycale species in the Mediterranean within what was considered until now Hemimycale columella. The new species that we name Hemimycale mediterranean sp. nov. (see description below) has a shallower distribution across the whole Mediterranean than $H$. columella, which has Atlantic affinities. $H$. columella differs from $H$. mediterranea in $0.85 \%$ (18S rRNA), $1.23 \%$ (28S rRNA), and in $1-1.2 \%$ (COI).

The lack of genetic diversity among the distant populations of $H$. mediterranea analyzed points to its recent presence in the Mediterranean, which is compatible with a recent introduction. However, the new species has not been recorded out of the Mediterranean and thus, its origin cannot be established at the present time.

Many cryptic species that were revealed by molecular markers have never been formally described owing to the difficulty of finding diagnostic phenotypic characters. Although after exhaustive observation, only slight, morphological differences have been found to differentiate $H$. mediterranea sp. nov. from $H$. columella (see species description below), these phenotypic differences are consistent across individuals and thus, add to molecular differences and biological traits (Garate et al., unpublished) to consistently differentiate these two species.

Species description

Genus Hemimycale Burton, 1934

Sequence accession Numbers GenBank (Table 1)

Type species Hemimycale columella (Bowerbank 1874)

Hemimycale is the only genus of Hymedesmiidae that has smooth diactines and monactines exclusively (Van Soest, 2002). The genus was described by Burton (1934) as "reduced Mycaleae 
with skeleton of loose fibers of styli, sometimes modified into anisostrongyles, running vertically to the surface; fibers tending to branch and anastomose; no special dermal skeleton, no microscleres".

The spicule complement described by Burton, however, seems different from that reported in the several modern redescriptions of $H$. columella (Vacelet, Donadey \& Froget, 1987), which report predominant straight anisostrongyles with rare or absent styles. Indeed, Burton stated that the Bowerbank representation of $H$. columella spicules was wrong because it figured anisostrongyles instead of styles, and was precisely the dominance of styles what induced Burton to place the species among the Mycaleae. The termination of the diactines either round or pointed ends may be the result of different silica concentration in the water masses, as reported for other siliceous sponge skeletons (Uriz, 2006), but it cannot be totally discarded that the Burton H. columella belonged in another Hemimycale species.

Species: H. columella (Bowerbank, 1874)

Sequence accession Numbers GenBank (Table 1)

Description (Fig. 3A-D): Encrusting to massive sponges. Surface smooth, covered with circular inhaling, areas up to $6 \mathrm{~mm}$ in diameter with an up to $3 \mathrm{~mm}$ high rim. Morbid and fleshy consistence. Translucent to whitish ectosome, difficult to separate from the choanosome. Thousands of calcareous spherules, $1 \mu \mathrm{m}$ in diameter formed by intracellular calcifying bacteria (Uriz et al., 2012) are spread through the sponge mesohyl and specially accumulated at the sponge periphery of whitish individuals (Garate et al., unpublished data).

Color from pinkish-orange to whitish outside, dark orange inside.

Spicules (Table 3, Fig. 4F): asymmetric strongyles (anysotrongyles), straight, 302-435 $\mu \mathrm{m}$ x 3-4 $\mu \mathrm{m}$ in size. Styles rare or completely absent from the Mediterranean specimens (this study) and Canary Islands (Cruz 2002).

Skeletal arrangement: plumose branching bundles of anysostrongyles together with spread spicules. A palisade of vertical anysotrongyles forms the rim around the inhaling areas. Distribution: Northeastern Atlantic (United Kingdom and Ireland coasts) Canarias Islands (Cruz 2002), western Mediterranean: Tossa de Mar, Arenys de Mar, from 28 to $60 \mathrm{~m}$ depth (this study). It is not possible to confirm whether previous Mediterranean records of the species (see Vacelet \& Donadey, 1977) belonged to H. columella or to H. mediterranea. 
Biology: multiannual life span, ca. $60 \%$ survival after two monitoring years; maximum growth in autumn-winter (Garate et al., unpublished data). Larval release occurs at the beginning of November in Mediterranean populations (authors unpublished obs.).

Species: H. mediterranea sp. nov. (Fig. 3E-H)

Sequence accession Numbers GenBank (Table 1)

Description: thick encrusting sponges with aerolate inhaling areas up to $3 \mathrm{~mm}$ in diameter, surrounded by an up to $1.5-2 \mathrm{~mm}$ high rim, which in some cases barely surpasses the sponge surface. Thousands of calcareous spherules, $1 \mu \mathrm{m}$ in diameter formed by intracellular calcifying bacteria are spread through the sponge mesohyl and specially accumulated at the sponge periphery (Garate et al., in press).

Ectosome: firmly attached to the choanosome.

Color: flesh to clear brownish externally, more o less whitish depending on calcibacteria accumulation at the surface, sometimes partially covered by an epibiotic (reddish or pinkish) cyanobacteria.

Spicules (Table 3, Fig. 4A-E): smooth, uniform in size, straight, anysostrongyles, 200-296 x 3-4 $\mu \mathrm{m}$ in size. Styles completely absent.

Skeletal arrangement: plumose undulating bundles of anysostrongyles together with spread spicules. A palisade of vertical anysotrongyles forms the rim around the inhaling areas. Known distribution: Northwestern Mediterranean, central Mediterranean, Adriatic, eastern Mediterranean (Spain: Cap De Creus, Tossa, Blanes, Arenys, South Italy: Croatia, Tremiti, Turkey, Greece) between 3 and $17 \mathrm{~m}$ deep.

Biology: annual life span, maximum growth rates in summer (authors unpublished data). Larval release at the end of September beginning of October (authors unpublished obs.).

In most cases, it is difficult to ascertain whether individuals of $H$. columella recorded by other authors belong in H. columella or H. mediterranea. The redescription of $H$. columella by Van Soest (2002) based on the holotype (from the Atlantic) reported large aerolate porefields with elevated rims, which are shared with the deep Mediterranean specimens of H. columella (Fig. 3A-D) in contrast to the small, short-rimmed porefields showed by H. mediterranea sp. nov. Both species have mainly straight slightly asymmetric strongyles but the spicule sizes are 
402

systematically larger in $H$. columella (Table 3 ). However, while styles were rarely present in $H$. columella individuals, they have not been found in specimens of $H$. mediterranea sp. nov. The external color also differs between the two species, being orange to pinkish in H. columella and flesh color to brownish H. mediterranea sp. nov. (Fig. 3E-H). Vacelet \& Donadey (1977) reported two different color forms occurring side by side on the littoral of Provence (France), one pink cream and the other one brownish. Likely the second color morph, which besides had smaller strongyles, corresponded to the H. mediterranea sp. nov.

Color has not received much attention as a diagnostic character in sponges because it has been generally considered to be a response to higher or lower light irradiance at the sponge habitat, or to the presence of epibiotic or symbiotic cyanobacteria. However, color has proven to be taxonomically relevant to distinguish other invertebrates such as shrimp species (Knowlton \& Mills, 1992) and also sponge species of the genus Scopalina (Blanquer \& Uriz, 2008), and thus it seems worthy to be taken into account in sponge taxonomy.

The slight phenotypic differences found between the two species appear, however, consistent across individuals and localities within the Atlanto-Mediterranean basin. Moreover, their ecological distribution and bacterial symbionts, strongly differentiate these two cryptic species. For instance, although calcareous spherules produced by intracellular bacteria are present in the two species, the producer bacteria belong in different species (Garate et al., in press), and the respective microbial communities totally differ (Garate et al., in press). Symbionts, as predators do (e. g. Wulff, 2006), often distinguish their target sponge preys or hosts while the species remain morphologically cryptic to taxonomists. Moreover, $H$. mediterranea sp. nov. shows an annual life span, with individuals disappearing after larval release, while $H$. columella has a multiannual life span (authors unpublished data) and growth dynamics also differs between the two species, as H. mediterranea sp. nov. grows more in summer, while $H$. columella grows preferentially in autumn-winter (authors unpublished data).

The contrasting ecological distribution of these two cryptic species in the Mediterranean helps to predict their identity in the field. H. mediterranean sp. nov. inhabits shallower zones than $H$. columella. However, it is likely that both species may share occasionally habitat, as the record of the two color morphs side by side (Vacelet \& Donadey, 1977) indicate. $H$. mediterranea sp. nov. seems to be more abundant and widespread in the Mediterranean than $H$. 
columella. Molecular differences between groups of individuals of $H$. columella suggest the possible presence of additional cryptic species among the deep Mediterranean Hemimycale.

The presence of two morphologically cryptic Hemimycale species in the Mediterranean, which show contrasting biological traits, reinforces the idea that cryptic species represent something more than wrong taxonomic identifications or biodiversity underestimates. They may feature contrasting biological cycles and life spans, and puzzle biological studies, which may invalidate conservation policies based on those studies.

Acknowledgements

We thank J. Sureda, M. Bolivar, and F. Crespo for sampling support in the Mediterranean Sea. M. Bolivar also provided some deep Hemimycale pictures. X. Turon and E. Ballesteros provided samples of H. arabica from the Read Sea and Crella cyathophora from Bempton Islands (Pacific), respectively.

References

Appeltans W., Ahyong ST., Anderson G., Angel MV., Artois T., Bailly N., Appeltans W., Ahyong ST., Anderson G., Angel MV., Artois T., Bailly N., Bamber R., Barber A., Bartsch I., Berta A., Błażewicz-Paszkowycz M., Bock P., Boxshall G., Boyko CB., Brandão SN., Bray RA., Bruce NL., Cairns SD., Chan TY., Cheng L., Collins AG., Cribb T., CuriniGalletti M., Dahdouh-Guebas F., Davie PJ., Dawson MN., De Clerck O., Decock W., De Grave S., de Voogd NJ., Domning DP., Emig CC., Erséus C., Eschmeyer W., Fauchald K., Fautin DG., Feist SW., Fransen CH., Furuya H., Garcia-Alvarez O., Gerken S., Gibson D., Gittenberger A., Gofas S., Gómez-Daglio L., Gordon DP., Guiry MD., Hernandez F., Hoeksema BW., Hopcroft RR., Jaume D., Kirk P., Koedam N., Koenemann S., Kolb JB., Kristensen RM., Kroh A., Lambert G., Lazarus DB., Lemaitre R., Longshaw M., Lowry J., Macpherson E., Madin LP., Mah C., Mapstone G., McLaughlin PA., Mees J., Meland K., Messing CG., Mills CE., Molodtsova TN., Mooi R., Neuhaus B., Ng PK., Nielsen C., Norenburg J., Opresko DM., Osawa M., Paulay G., Perrin W., Pilger JF., Poore GC., Pugh P., Read GB., Reimer JD., Rius M., Rocha RM., Saiz-Salinas JI., Scarabino V., Schierwater B., Schmidt-Rhaesa A., Schnabel KE., Schotte M., Schuchert P., Schwabe E., Segers H., Self-Sullivan C., Shenkar N., Siegel V., Sterrer W., Stöhr S., Swalla B., Tasker ML., 
Thuesen EV., Timm T., Todaro MA., Turon X., Tyler S., Uetz P, van der Land J., Vanhoorne B., van Ofwegen LP., van Soest RW., Vanaverbeke J., Walker-Smith G., Walter TC., Warren A., Williams GC., Wilson SP., Costello MJ. 2012. The magnitude of global marine species diversity. Current Biology 22:2189-2202. DOI: 10.1016/j.cub.2012.09.036. 2012. The magnitude of global marine species diversity. Current Biology 22:2189-2202. DOI: 10.1016/j.cub.2012.09.036.

Blanquer A., Uriz MJ. 2007. Cryptic speciation in marine sponges evidenced by mitochondrial and nuclear genes: A phylogenetic approach. Molecular Phylogenetics and Evolution 45:392-397. DOI: 10.1016/j.ympev.2007.03.004.

Blanquer A., Uriz MJ. 2008. “A posteriori” searching for phenotypic characters to describe new cryptic species of sponges revealed by molecular markers (Dictyonellidae: Scopalina). Invertebrate Systematics 22:489-502. DOI: 10.1071/IS07004.

Blanquer A., Uriz MJ., Agell G. 2008. Hidden diversity in sympatric sponges: Adjusting lifehistory dynamics to share substrate. Marine Ecology Progress Series 371:109-115. DOI: 10.3354/meps07679.

Blanquer A., Uriz MJ., Caujapé-Castells J. 2009. Small-scale spatial genetic structure In Scopalina lophyropoda, an encrusting sponge with philopatric larval dispersal and frequent fission and fusion events. Marine Ecology Progress Series 380:95-102. DOI: 10.3354/meps07931.

Boury-Esnault N., Pansini M., Uriz MJ. (1993). Cosmopolitism in sponges: The "complex" Guitarra fimbriata with description of a new species of Guitarra from the northeast Atlantic. Scientia Marina 57: 367-373.

De Caralt S., López-Legentil S., Tarjuelo I., Uriz MJ., Turon X. 2002. Contrasting biological traits of Clavelina lepadiformis (Ascidiacea) populations from inside and outside harbours in the western Mediterranean. Marine Ecology Progress Series 244:125-137. DOI: 10.3354/meps244125.

Carella M., Agell G., Cárdenas P., Uriz MJ. 2016. Phylogenetic reassessment of antarctic Tetillidae (Demospongiae, Tetractinellida) reveals new genera and genetic similarity among morphologically distinct species. PLoS ONE 11:1-33. DOI: 10.1371/journal.pone.0160718. Castresana J. 2000. Selection of conserved blocks from multiple alignments for their use in phylogenetic analysis. Molecular Biology and Evolution 17:540-552. DOI: 
10.1093/oxfordjournals.molbev.a026334.

Cárdenas P., Rapp HT. 2012. A review of Norwegian streptaster-bearing Astrophorida (Porifera: Demospongiae: Tetractinellida), new records and a new species. Zootaxa 52:1-52.

Duran S., Pascual M., Turon X. 2004. Low levels of genetic variation in mtDNA sequences over the western Mediterranean and Atlantic range of the sponge Crambe crambe (Poecilosclerida). Marine Biology 144:31-35. DOI: 10.1007/s00227-003-1178-5.

Folmer O., BLACK M., HOEH W., Lutz R., Vrijenhoek R. 1994. DNA primers for amplification of mitochondrial cytochrome $\mathrm{c}$ oxidase subunit I from diverse metazoan invertebrates. Molecular Marine Biology and Biotechnology 3:294-299. DOI: 10.1371/journal.pone.0013102.

Forsman ZH., Concepcion GT., Haverkort RD., Shaw RW., Maragos JE., Toonen RJ. 2010. Ecomorph or endangered coral? DNA and microstructure reveal hawaiian species complexes: Montipora dilatatal flabellata/turgescens \& M. patula/verrilli. PLoS ONE 5. DOI: 10.1371/journal.pone.0015021.

Frainer A., McKie BG., Malmqvist B. 2014. When does diversity matter? Species functional diversity and ecosystem functioning across habitats and seasons in a field experiment. Journal of Animal Ecology 83:460-469. DOI: 10.1111/1365-2656.12142.

Garate L., Sureda J., Agell G., Uriz MJ. Endosymbiotic calcifying bacteria across sponge species and oceans. Scientific Reports (in press).

Gascuel O., Steel M. 2006. Neighbor-joining revealed. Molecular Biology Evolution 23 (11): 1997-2000. doi:10.1093/molbev/msl072. PMID 16877499

González-Ramos J., Agell G., Uriz M. 2015. Microsatellites from sponge genomes: the number necessary for detecting genetic structure in Hemimycale columella populations. Aquatic Biology 24:25-34. DOI: 10.3354/ab00630.

Guardiola M., Frotscher J., Uriz MJ. 2012. Genetic structure and differentiation at a short-time scale of the introduced calcarean sponge Paraleucilla magna to the western Mediterranean. Hydrobiologia 687:71-84. DOI: 10.1007/s10750-011-0948-1.

Guardiola M., Frotscher J., Uriz M-J. 2016. High genetic diversity, phenotypic plasticity, and invasive potential of a recently introduced calcareous sponge, fast spreading across the Atlanto-Mediterranean basin. Marine Biology 163:123. DOI: 10.1007/s00227-016-2862-6. Guindon S., Gascuel O. 2003. A simple, fast, and accurate algorithm to estimate large 
phylogenies by maximum likelihood. Systematic Biology 52:696-704. DOI:

$10.1080 / 10635150390235520$.

Guindon S., Lethiec F., Duroux P., Gascuel O. 2005. PHYML Online - A web server for fast maximum likelihood-based phylogenetic inference. Nucleic Acids Research 33:557-559. DOI: $10.1093 /$ nar/gki352.

Hooper JNA., Lévi C. 1994. Biogeography of Indo-west Pacific sponges: Microcionidae, Raspailiidae, Axinellidae. In: Van Soest, van Kempen \& Braekman eds. Sponges in time and space. Rotterdam: Balkema, 191-212.

Kearse M., Moir R., Wilson A., Stones-Havas S., Cheung M., Sturrock S., Buxton S., Cooper A., Markowitz S., Duran C., Thierer T., Ashton B., Meintjes P., Drummond A. 2012. Geneious Basic: An integrated and extendable desktop software platform for the organization and analysis of sequence data. Bioinformatics 28:1647-1649. DOI: 10.1093/bioinformatics/bts 199 .

Knapp IS., Godwin LS., Smith JE., Williams CJ., Bell JJ. 2011. Records of non-indigenous marine species at Palmyra Atoll in the US Line Islands. Marine Biodiversity Records 4:e30. DOI: $10.1017 / \mathrm{S} 1755267211000078$.

Knowlton N. 1993. Sibling species in the sea. Annual review of ecology and systematics 24, 189-216. doi: 10.1146/annurev.es.24.110193.001201

Knowlton N., Jackson JBC. 1994. New taxonomy and niche partitioning on coral reefs: Jack of all trades or master of some? Trends in Ecology and Evolution 9:7-9. DOI: 10.1016/01695347(94)90224-0.

Knowlton N., Mills DK. 1992. The systematic importance of color and color pattern: evidence for complexes of sibling species of snapping shrimp (Caridea: Alpheidae: Alpheus) from the Caribbean and Pacific coasts of Panama. Proceedings of the San Diego Society of Natural History 18:1-5.

Lévi, C. 1973. Systématique de la Clase Demospongiaria (Demosponges). In: Masson \& Cie eds. Traité de Zoologie. Anatomie, systématique, Biologie. III Spongiaires, 1 Anatomie, Physiologie, Systématique, Écologie. Paris. 577-631.

López-Legentil S., Ruchty M., Domenech A., Turon X. 2005. Life cycles and growth rates of two morphotypes of Cystodytes (Ascidiacea) in the western Mediterranean. Marine Ecology Progress Series 296:219-228. DOI: 10.3354/meps296219. 
Loreau M. 2004. Does functional redundancy exist? Oikos 104:606-611.

Medlin L., Elwood HJ., Stickel S., Sogin ML. 1988. The characterization of enzymatically amplified eukaryotic 16S-like rRNA-coding regions. Gene 71:491-499. DOI: 10.1016/0378-1119(88)90066-2.

de Meester N., Gingold R., Rigaux A., Derycke S., Moens T. 2016. Cryptic diversity and ecosystem functioning: a complex tale of differential effects on decomposition. Oecologia 182:1-13. DOI: 10.1007/s00442-016-3677-3.

Mariani S., Uriz M., Turon X., Alcoverro T. 2006. Dispersal strategies in sponge larvae: Integrating the life history of larvae and the hydrologic component. Oecologia 149: 174184

Morrow CC., Picton BE., Erpenbeck D., Boury-Esnault N., Maggs CA., Allcock AL. 2012. Congruence between nuclear and mitochondrial genes in Demospongiae: A new hypothesis for relationships within the G4 clade (Porifera: Demospongiae). Molecular Phylogenetics and Evolution 62:174-190. DOI: 10.1016/j.ympev.2011.09.016.

Nichols S A., Barnes PAG. 2005. A molecular phylogeny and historical biogeography of the marine sponge genus Placospongia (Phylum Porifera) indicate low dispersal capabilities and widespread crypsis. Journal of Experimental Marine Biology and Ecology 323:1-15

de Paula TS., Zilberberg C., Hajdu E., Lôbo-Hajdu G. 2012. Morphology and molecules on opposite sides of the diversity gradient: four cryptic species of the Cliona celata (Porifera, Demospongiae) complex in South America revealed by mitochondrial and nuclear markers. Molecular phylogenetics and evolution 62:529-41. DOI: 10.1016/j.ympev.2011.11.001.

Payo DA., Leliaert F., Verbruggen H., D’hondt S., Calumpong HP., De Clerck O. 2013. Extensive cryptic species diversity and fine-scale endemism in the marine red alga Portieria in the Philippines. Proceedings. Biological sciences / The Royal Society 280:20122660. DOI: $10.1098 / \mathrm{rspb} .2012 .2660$.

Pérez-Porro a. R., González J., Uriz MJ. 2012. Reproductive traits explain contrasting ecological features in sponges: The sympatric poecilosclerids Hemimycale columella and Crella elegans as examples. Hydrobiologia 687:315-330. DOI: 10.1007/s10750-011-0919-6.

Pérez-Portela R., Duran S., Palacín C., Turon X. 2007. The genus Pycnoclavella (Ascidiacea) in the Atlanto-Mediterranean region : a combined molecular and morphological approach. Invertebrate Systematics 21:187-205. DOI: 10.1071/IS06015. 
Posada D. 2008. jModelTest: Phylogenetic model averaging. Molecular Biology and Evolution 25:1253-1256. DOI: 10.1093/molbev/msn083.

Prada C., McIlroy SE., Beltrán DM., Valint DJ., Ford SA., Hellberg ME., Coffroth MA. 2014.

Cryptic diversity hides host and habitat specialization in a gorgonian-algal symbiosis. Molecular Ecology 23:3330-3340. DOI: 10.1111/mec.12808.

Redmond NE., Morrow CC., Thacker RW., Diaz MC., Boury-Esnault N., Cárdenas P., Hajdu E., Lôbo-Hajdu G., Picton BE., Pomponi SA., Kayal E., Collins AG. 2013. Phylogeny and systematics of demospongiae in light of new small-subunit ribosomal DNA (18S) sequences. Integrative and Comparative Biology 53:388-415. DOI: 10.1093/icb/ict078.

Reveillaud J., Allewaert Ć., Ṕrez T., Vacelet J., Banaigs B., Vanreusel A. 2012. Relevance of an integrative approach for taxonomic revision in sponge taxa: Case study of the shallow-water Atlanto-Mediterranean Hexadella species (Porifera : ae :Verongida). Invertebrate Systematics 26:230-248. DOI: 10.1071/IS11044.

Reveillaud J., Van Soest R., Derycke S., Picton B., Rigaux A., Vanreusel A. 2011. Phylogenetic relationships among NE atlantic Plocamionida Topsent (1927) (Porifera, Poecilosclerida): Under-estimated diversity in reef ecosystems. PLoS ONE 6. DOI:

10.1371/journal.pone.0016533.

Ronquist F., Huelsenbeck JP. 2003. MrBayes 3: Bayesian phylogenetic inference under mixed models. Bioinformatics 19:1572-1574. DOI: 10.1093/bioinformatics/btg180.

Swofford D.L. 2002. Phylogenetic analysis using parsimony (* and other methods). Version 4. Sunderland, MA: Sinauer Associates

Tarjuelo I., Posada D., Crandall KA., Pascual M., Turon X. 2001. Cryptic species of Clavelina (Ascidiacea) in two different habitats: Harbours and rocky littoral zones in the northwestern Mediterranean. Marine Biology 139:455-462. DOI: 10.1007/s002270100587.

Thacker RW., Hill AL., Hill MS., Redmond NE., Collins AG., Morrow CC., Spicer L., Carmack CA., Zappe ME., Pohlmann D., Hall C., Diaz MC., Bangalore P V. 2013. Nearly complete 28S rRNA gene sequences confirm new hypotheses of sponge evolution. Integrative and Comparative Biology 53:373-387. DOI: 10.1093/icb/ict071.

Uriz, MJ. 2006. Mineral skeletogenesis in sponges. Canadian Journal Zoology 84: 322-356

Uriz MJ., Agell G., Blanquer A., Turon X., Casamayor EO. 2012. Endosymbiotic Calcifying Bacteria: A New Cue To The Origin Of Calcification In Metazoa? Evolution 66:2993-2999. 
DOI: 10.1111/j.1558-5646.2012.01676.x.

Uriz MJ., Maldonado M., Turon X., Martí R. 1998. How do reproductive output, larval behaviour, and recruitment contribute to adult spatial patterns in Mediterranean encrusting sponges? Marine Ecology Progress Series 167:137-148. DOI: 10.3354/meps167137.

Uriz MJ., Rossell D., Martín D. 1992. The sponge population of Cabrera Archipelago (Balearic Islands): characteristics, distribution, and abundance of the most representative species. Marine Ecology 13:101-117. DOI: 10.1111/j.1439-0485.1992.tb00343.x.

Uriz MJ., Turon X. 2012. Sponge ecology in the molecular era. Advances in Marine Biology 61:345-410. DOI: 10.1016/B978-0-12-387787-1.00006-4.

Uriz MJ., Turon X., Mariani S. 2008. Ultrastructure and dispersal potential of sponge larvae: Tufted versus evenly ciliated parenchymellae. Marine Ecology 29:280-297. DOI: 10.1111/j.1439-0485.2008.00229.x.

Vacelet J., Donadey C. 1977. Electron microscope study of the association between some sponges and bacteria. Journal of Experimental Marine Biology and Ecology 30:301-314. DOI: 10.1016/0022-0981(77)90038-7.

Vacelet J., Donadey C., Froget C. 1987. The calcium carbonate spherules of Hemimycale columella (Demosponges, Poecilosclerida) and their taxonomic value. In: Vacelet \& BouryEsnault eds. Taxonomy of Porifera. NATO ASI Series, G13. Berlin: Springer-Verlague. 259-274.

Van Soest RWM. 2002. Family Hymedesmiidae Topsent, 1928. Systema Porifera:575-593. DOI: 10.1007/978-1-4615-0747-5_62.

Van Soest RWM., Boury-Esnault N., Vacelet J., Dohrmann M., Erpenbeck D., de Voogd NJ., Santodomingo N., Vanhoorne B., Kelly M., Hooper JNA. 2012. Global diversity of sponges (Porifera). PLoS ONE 7. DOI: 10.1371/journal.pone.0035105.

Van Soest RWM., Boury-Esnault N., Hooper JNA.,; Rützler K., de Voogd NJ., Alvarez de Glasby B., Hajdu E., PiseraAB., Manconi R., Schoenberg, C., Klautau, M., Picton B.,Kelly M., Vacelet J., Dohrmann M., Díaz M-C., Cárdenas P., Carballo J L. 2016. World Porifera database. Accessed at http://www.marinespecies.org/porifera on 2016-12-19

Vargas S., Dohrmann M., Göcke C., Janussen D., Wörheide G. 2016. Nuclear and mitochondrial phylogeny of Rossella (Hexactinellida: Lyssacinosida, Rossellidae): a species and a species flock in the Southern Ocean. bioR xiv. DOI: 10.1101/037440. 
649 Wulff JL. 2006. Sponge systematics by starfish: Predators distinguish cryptic sympatric species 650 of caribbean fire sponges, Tedania ignis and Tedania klausi n. sp. (Demospongiae, 651 Poecilosclerida). Biological Bulletin 211:83-94. DOI: 10.2307/4134581. 


\section{Figure 1}

Phylogenetic tree using concatenated (18S rRNA+COI) partitions

$\mathrm{BI}, \mathrm{NJ}$ and $\mathrm{ML}$ gave the same topologies. Posterior probability, neighbor joining, and maximum likelihood supporting values are at the base of clades. 
$18 S+28 S$

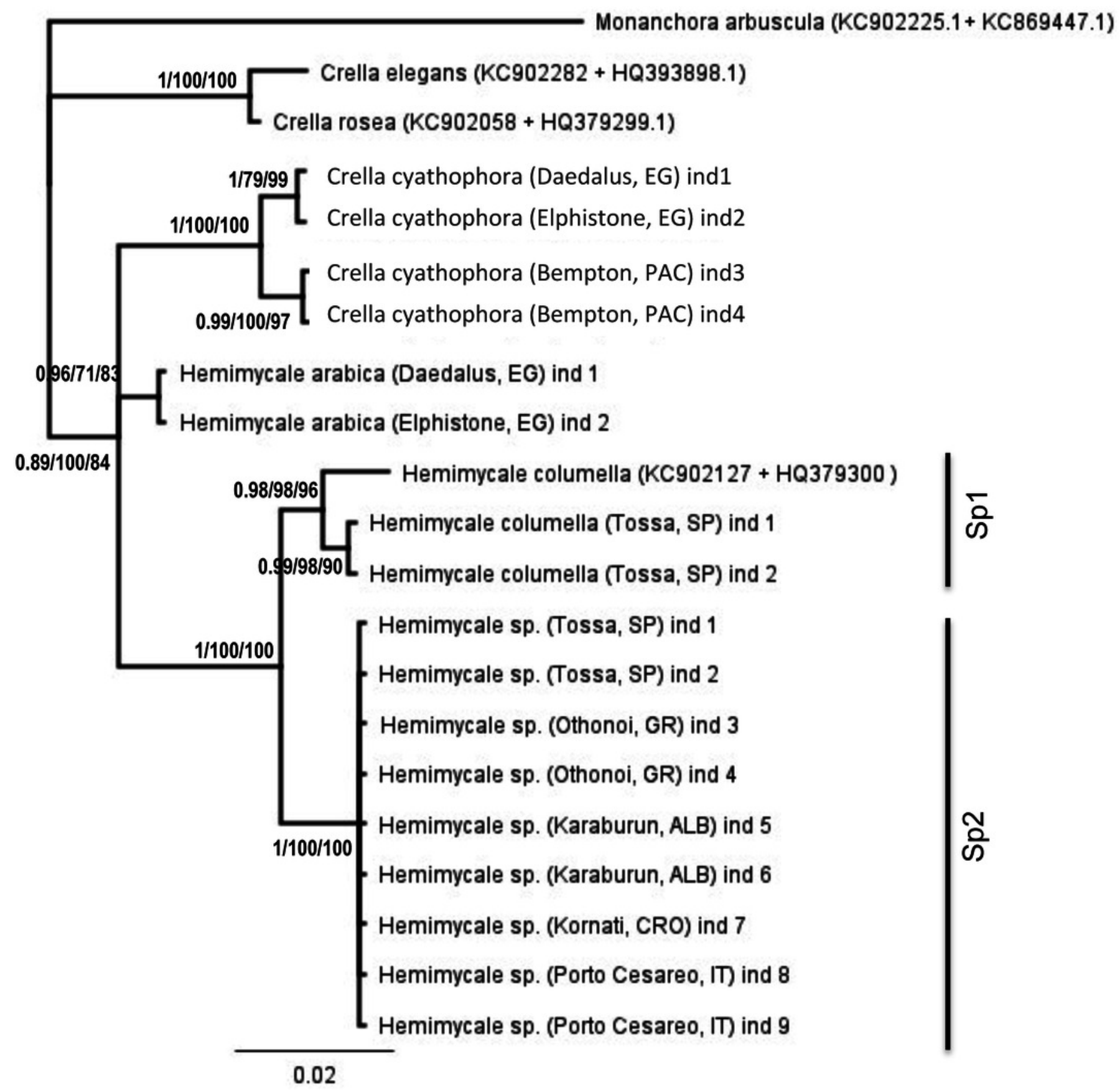

$\mathrm{BI} / \mathrm{NJ} / \mathrm{ML}$ 


\section{Figure 2}

Phylogenetic tree using concatenated $(18 \mathrm{~S}+28 \mathrm{~S}$ rRNA) partitions

$\mathrm{BI}, \mathrm{NJ}$ and $\mathrm{ML}$ gave the same topologies. Posterior probability, neighbor joining, and maximum likelihood supporting values are at the base of clades.

$$
18 \mathrm{~S}+\mathrm{COI}
$$

Crella elegans (AY348882+ KC902282)

Crella elegans (JF440338+ JF440338)

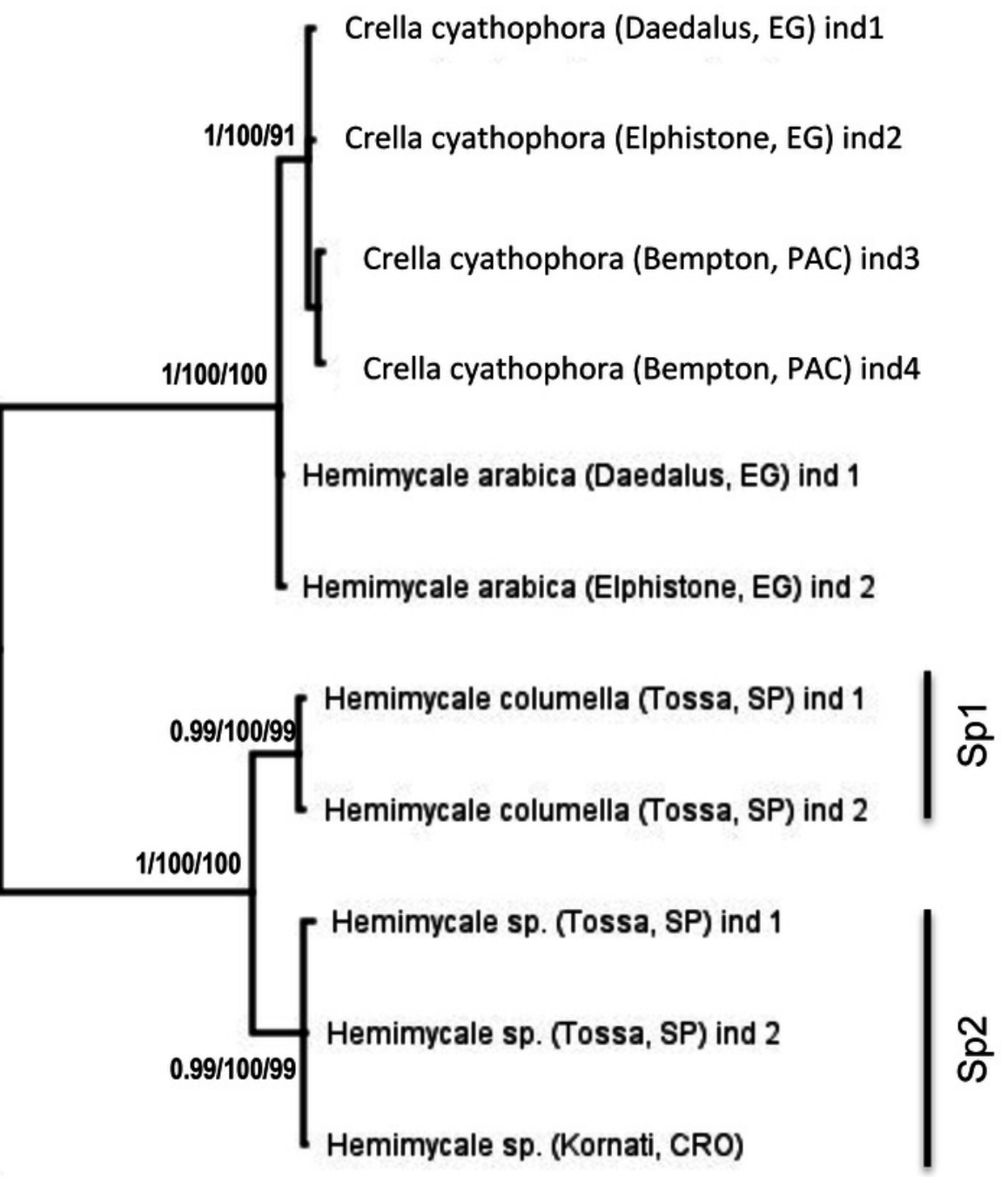




\section{Figure 3}

In situ pictures of Atlanto-Mediterranean Hemimycale spp

A, B, C, D) Hemimycale columella from 35-40 m of depth. E, F, G, H) Hemimycale mediterranea sp. nov. from 12-17 m of depth. Whitish tinge is due to calcibacteria accumulation. Red tinges are due to several species of epibiotic cyanobacteria. Arrows point to aerolate inhaling areas; arrowheads indicate the epibiont cyanophycea on $\mathrm{H}$. mediterranea specimens 

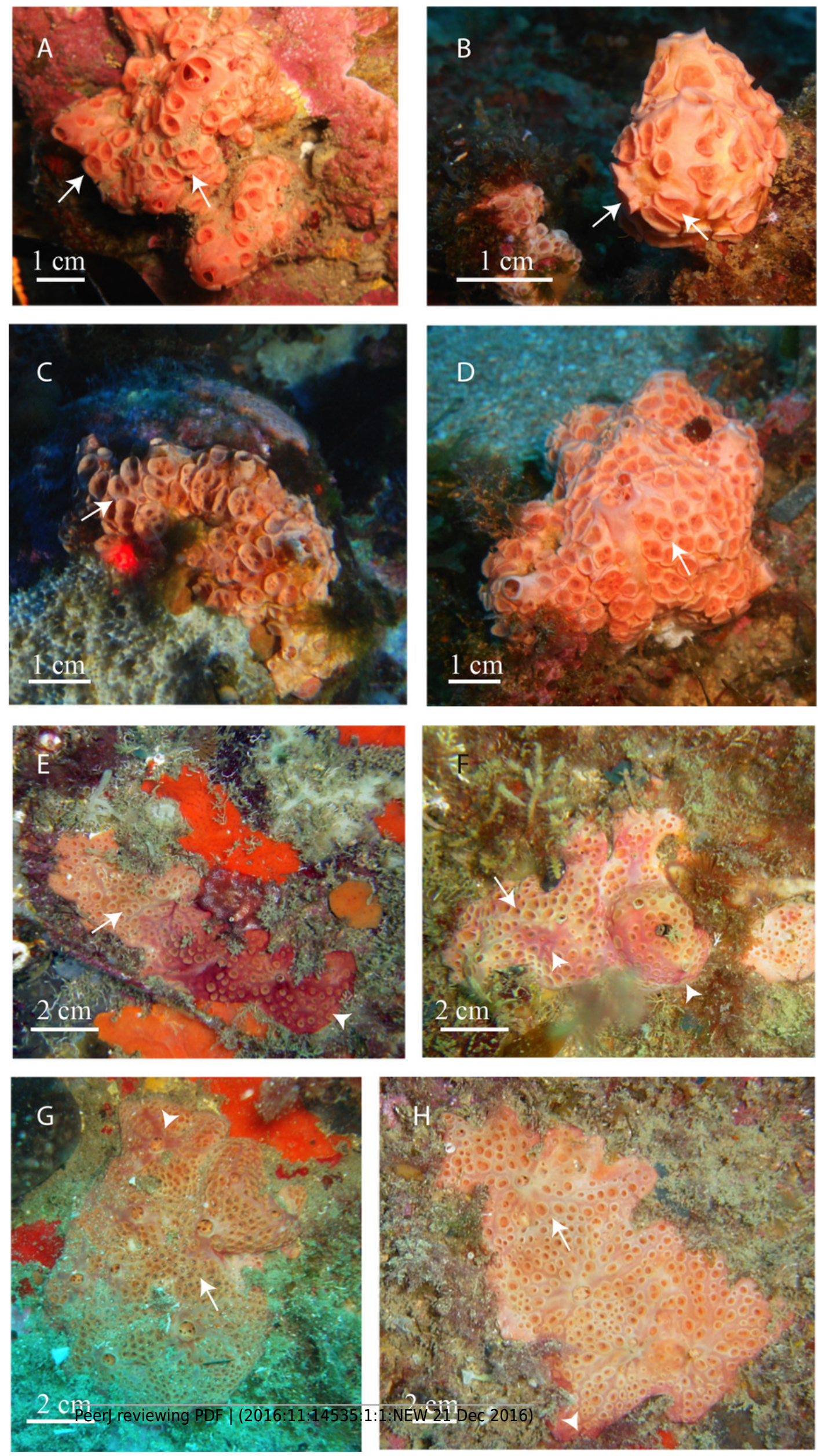


\section{Figure 4}

Spicules of Hemimycale spp. and Crella cyathophora though SEM

A, B, C, D, E) Anysostrongyles (Hemimycale mediterranea). F) Anisostrongyles (Hemimycale columella). G) Anisostrongyles and one style (Hemimycale arabica). H) Anysotrongyles and acantoxeas (Crella cyatophora). Inserts on each picture correspond to magnifications of the spicule ends.

*Note: Auto Gamma Correction was used for the image. This only affects the reviewing manuscript. See original source image if needed for review. 

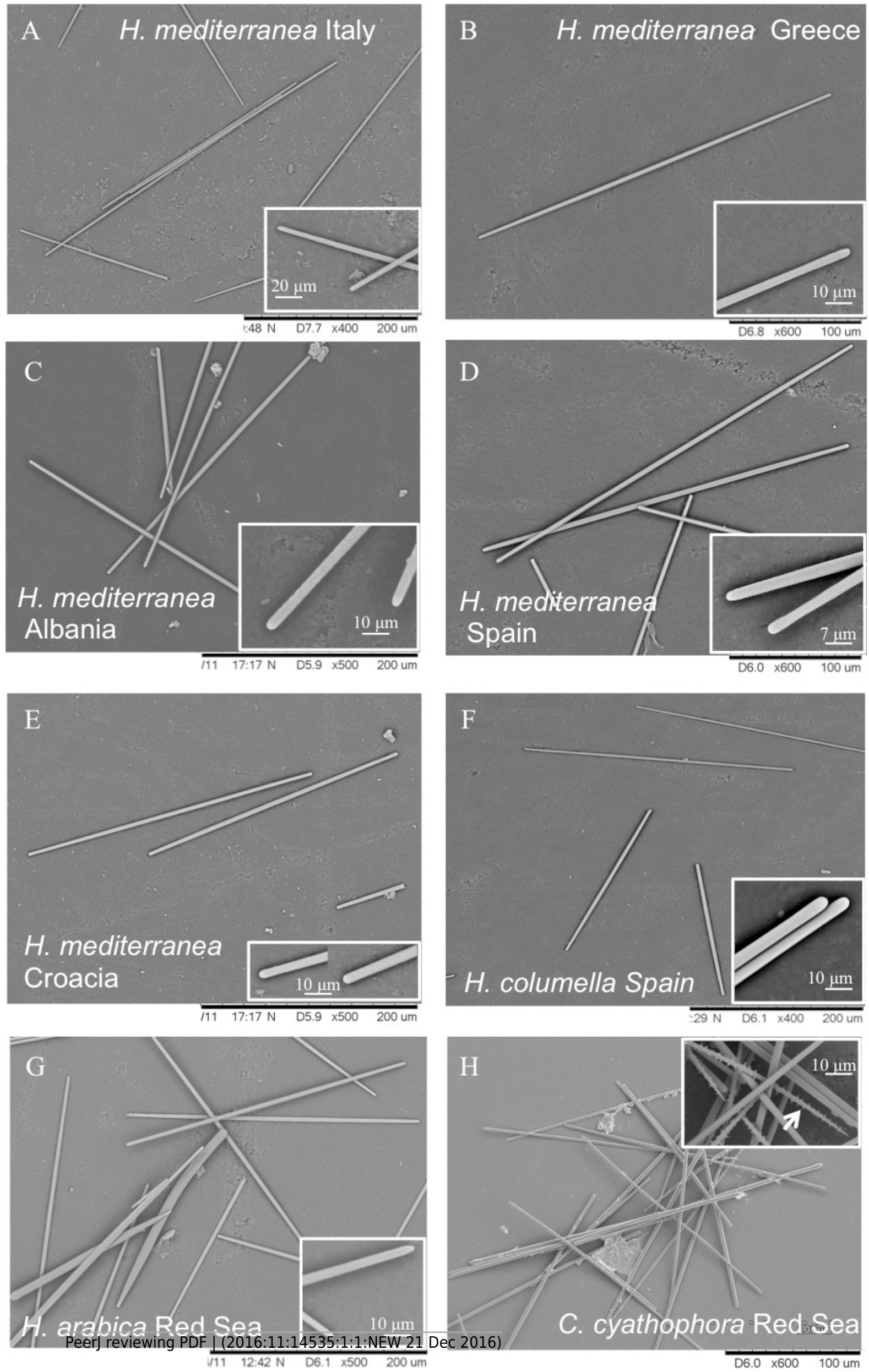


\section{Table $\mathbf{1}$ (on next page)}

Geographical origin and ecological distribution of the individuals used in the phylogenetic study, with accession numbers

Individuals sequenced de novo are in bold 


\begin{tabular}{|c|c|c|c|c|}
\hline Species & Sea/Ocean & Locality & $\begin{array}{l}\text { Voucher } \\
\text { numbers }\end{array}$ & $\begin{array}{l}\text { Accession } \\
\text { numbers }\end{array}$ \\
\hline H. arabica ind. 1 & Red Sea & $\begin{array}{l}\text { Dedalos- } \\
\text { Brother Islands }\end{array}$ & $\begin{array}{l}\text { CEAB.POR.G } \\
\text { EN.001 }\end{array}$ & $\begin{array}{l}\text { COI: } \\
\text { KY002124 } \\
\text { 18S: } \\
\text { KY002171 } \\
\text { 28S: } \\
\text { KY002181 }\end{array}$ \\
\hline H. arabica ind. 2 & Red Sea & $\begin{array}{l}\text { Elphistone- } \\
\text { Brother Islands }\end{array}$ & $\begin{array}{l}\text { CEAB.POR.G } \\
\text { EN.002 }\end{array}$ & $\begin{array}{l}\text { COI: } \\
\text { KY002125 } \\
\text { 18S: } \\
\text { KY002172 } \\
\text { 28S: } \\
\text { KY002182 } \\
\end{array}$ \\
\hline H. columella & $\begin{array}{l}\text { Northeastern } \\
\text { Atlantic }\end{array}$ & $\begin{array}{l}\text { Plymouth, } \\
\text { Wales-UK }\end{array}$ & & $\begin{array}{l}28 \mathrm{~S}: \\
\text { HQ379300.1 } \\
\text { 18S: } \\
\text { KC902127.1 }\end{array}$ \\
\hline H. columella ind. 1 & $\begin{array}{l}\text { Northwestern } \\
\text { Mediterranean }\end{array}$ & $\begin{array}{l}\text { Arenys de Mar- } \\
\text { Spain }\end{array}$ & $\begin{array}{l}\text { CEAB.POR.G } \\
\text { EN.003 }\end{array}$ & $\begin{array}{l}\text { 28S: } \\
\text { KY002183 }\end{array}$ \\
\hline H. columella ind. 2 & $\begin{array}{l}\text { Northwestern } \\
\text { Mediterranean }\end{array}$ & $\begin{array}{l}\text { Arenys de Mar- } \\
\text { Spain }\end{array}$ & $\begin{array}{l}\text { CEAB.POR.G } \\
\text { EN.004 }\end{array}$ & $\begin{array}{l}\text { 28S: } \\
\text { KY002184 }\end{array}$ \\
\hline H. columella ind. 3 & $\begin{array}{l}\text { Northwestern } \\
\text { Mediterranean }\end{array}$ & $\begin{array}{l}\text { Arenys de Mar- } \\
\text { Spain }\end{array}$ & $\begin{array}{l}\text { CEAB.POR.G } \\
\text { EN.005 }\end{array}$ & $\begin{array}{l}\text { COI: } \\
\text { KY002126 }\end{array}$ \\
\hline H. columella ind.1 & $\begin{array}{l}\text { Northwestern } \\
\text { Mediterranean }\end{array}$ & $\begin{array}{l}\text { Tossa de Mar- } \\
\text { Spain }\end{array}$ & $\begin{array}{l}\text { CEAB.POR.G } \\
\text { EN.006 }\end{array}$ & $\begin{array}{l}\text { COI: } \\
\text { KY002127 } \\
\text { 18S: } \\
\text { KY002160 } \\
\text { 28S: } \\
\text { KY002185 }\end{array}$ \\
\hline H. columella ind. 2 & $\begin{array}{l}\text { Northwestern } \\
\text { Mediterranean }\end{array}$ & $\begin{array}{l}\text { Tossa de Mar- } \\
\text { Spain }\end{array}$ & $\begin{array}{l}\text { CEAB.POR.G } \\
\text { EN.007 }\end{array}$ & $\begin{array}{l}\text { COI: } \\
\text { KY002128 } \\
\text { 18S: } \\
\text { KY002161 } \\
\text { 28S: } \\
\text { KY002186 }\end{array}$ \\
\hline H. columella ind. 3 & $\begin{array}{l}\text { Northwestern } \\
\text { Mediterranean }\end{array}$ & $\begin{array}{l}\text { Tossa de Mar- } \\
\text { Spain }\end{array}$ & $\begin{array}{l}\text { CEAB.POR.G } \\
\text { EN.008 }\end{array}$ & $\begin{array}{l}\text { COI: } \\
\text { KY002129 } \\
\text { 28S: } \\
\text { KY002187 }\end{array}$ \\
\hline H. columella ind. 4 & $\begin{array}{l}\text { Northwestern } \\
\text { Mediterranean }\end{array}$ & $\begin{array}{l}\text { Tossa de Mar- } \\
\text { Spain }\end{array}$ & $\begin{array}{l}\text { CEAB.POR.G } \\
\text { EN.009 }\end{array}$ & $\begin{array}{l}28 S: \\
\text { KY002188 }\end{array}$ \\
\hline $\begin{array}{l}\text { H. mediterranea sp. } \\
\text { nov. ind. } 1\end{array}$ & $\begin{array}{l}\text { Northwestern } \\
\text { Mediterranean }\end{array}$ & $\begin{array}{l}\text { Tossa de Mar- } \\
\text { Spain }\end{array}$ & $\begin{array}{l}\text { CEAB.POR.G } \\
\text { EN.010 }\end{array}$ & $\begin{array}{l}\text { COI: } \\
\text { KY002130 } \\
\text { 18S: } \\
\text { KY002162 } \\
28 S: \\
\text { KY002189 }\end{array}$ \\
\hline $\begin{array}{l}\text { H. mediterranea sp. } \\
\text { nov. ind. } 2\end{array}$ & $\begin{array}{l}\text { Northwestern } \\
\text { Mediterranean }\end{array}$ & $\begin{array}{l}\text { Tossa de Mar- } \\
\text { Spain }\end{array}$ & $\begin{array}{l}\text { CEAB.POR.G } \\
\text { EN.011 }\end{array}$ & $\begin{array}{l}\text { 18S: } \\
\text { KY002163 } \\
\text { 28S: } \\
\text { KY002190 }\end{array}$ \\
\hline $\begin{array}{l}\text { H. mediterranea sp. } \\
\text { nov. ind. } 4\end{array}$ & $\begin{array}{l}\text { Northwestern } \\
\text { Mediterranean }\end{array}$ & $\begin{array}{l}\text { Tossa de Mar- } \\
\text { Spain }\end{array}$ & $\begin{array}{l}\text { CEAB.POR.G } \\
\text { EN.012 }\end{array}$ & $\begin{array}{l}\text { COI: } \\
\text { KY002131 }\end{array}$ \\
\hline H. mediterranea sp. & Northwestern & Tossa de Mar - & CEAB.POR.G & COI: \\
\hline
\end{tabular}




\begin{tabular}{|c|c|c|c|c|}
\hline nov. ind. 5 & Mediterranean & Spain & EN.013 & KY002132 \\
\hline $\begin{array}{l}\text { H. mediterránea } \\
\text { sp. nov. ind. } 3\end{array}$ & Adriatic Sea & Koznati-Croatia & $\begin{array}{l}\text { CEAB.POR.G } \\
\text { EN.014 }\end{array}$ & $\begin{array}{l}\text { COI: } \\
\text { KY002134 }\end{array}$ \\
\hline $\begin{array}{l}\text { H. mediterránea } \\
\text { sp. nov. ind. } 7\end{array}$ & Adriatic Sea & Koznati-Croatia & $\begin{array}{l}\text { CEAB.POR.G } \\
\text { EN.015 }\end{array}$ & $\begin{array}{l}\text { 18S: } \\
\text { KY002170 } \\
\text { 28S: } \\
\text { KY002193 }\end{array}$ \\
\hline $\begin{array}{l}\text { H. mediterránea } \\
\text { sp. nov. ind. } 8\end{array}$ & Adriatic Sea & Koznati-Croatia & $\begin{array}{l}\text { CEAB.POR.G } \\
\text { EN.016 }\end{array}$ & $\begin{array}{l}\text { 28S: } \\
\text { KY002194 }\end{array}$ \\
\hline $\begin{array}{l}\text { H. mediterránea } \\
\text { sp. nov. ind. } 2\end{array}$ & Adriatic Sea & Tremity-Italy & $\begin{array}{l}\text { CEAB.POR.G } \\
\text { EN.017 }\end{array}$ & $\begin{array}{l}\text { COI: } \\
\text { KY002133 }\end{array}$ \\
\hline $\begin{array}{l}\text { H. mediterránea } \\
\text { sp. nov. ind. } 11\end{array}$ & Adriatic Sea & Tremity-Italy & $\begin{array}{l}\text { CEAB.POR.G } \\
\text { EN.018 }\end{array}$ & $\begin{array}{l}\text { 28S: } \\
\text { KY002199 }\end{array}$ \\
\hline $\begin{array}{l}\text { H. mediterránea } \\
\text { sp. nov. ind. } 8\end{array}$ & $\begin{array}{l}\text { Central } \\
\text { Mediterranean }\end{array}$ & $\begin{array}{l}\text { Porto Cesareo- } \\
\text { Italy }\end{array}$ & $\begin{array}{l}\text { CEAB.POR.G } \\
\text { EN.019 }\end{array}$ & $\begin{array}{l}\text { 18S: } \\
\text { KY002164 }\end{array}$ \\
\hline $\begin{array}{l}\text { H. mediterránea } \\
\text { sp. nov. ind. } 9\end{array}$ & $\begin{array}{l}\text { Central } \\
\text { Mediterranean }\end{array}$ & $\begin{array}{l}\text { Porto Cesareo- } \\
\text { Italy }\end{array}$ & $\begin{array}{l}\text { CEAB.POR.G } \\
\text { EN.020 }\end{array}$ & $\begin{array}{l}\text { 18S: } \\
\text { KY002165 } \\
\text { 28S: } \\
\text { KY002197 }\end{array}$ \\
\hline $\begin{array}{l}\text { H. mediterránea } \\
\text { sp. nov. ind. } 10\end{array}$ & $\begin{array}{l}\text { Central } \\
\text { Mediterranean }\end{array}$ & $\begin{array}{l}\text { Porto Cesareo- } \\
\text { Italy }\end{array}$ & $\begin{array}{l}\text { CEAB.POR.G } \\
\text { EN.021 }\end{array}$ & $\begin{array}{l}\text { 28S: } \\
\text { KY002198 }\end{array}$ \\
\hline $\begin{array}{l}\text { H. mediterránea } \\
\text { nov. sp. ind. } 5\end{array}$ & Adriatic Sea & $\begin{array}{l}\text { Karaburum- } \\
\text { Albania }\end{array}$ & $\begin{array}{l}\text { CEAB.POR.G } \\
\text { EN.022 }\end{array}$ & $\begin{array}{l}\text { 18S: } \\
\text { KY002166 } \\
\text { 28S: } \\
\text { KY002191 }\end{array}$ \\
\hline $\begin{array}{l}\text { H. mediterránea } \\
\text { nov. sp. ind. } 6\end{array}$ & Adriatic Sea & $\begin{array}{l}\text { Karaburum- } \\
\text { Albania }\end{array}$ & $\begin{array}{l}\text { CEAB.POR.G } \\
\text { EN.023 }\end{array}$ & $\begin{array}{l}\text { 18S: } \\
\text { KY002167 } \\
\text { 28S: } \\
\text { KY002192 }\end{array}$ \\
\hline $\begin{array}{l}\text { H. mediterránea } \\
\text { sp. nov. ind. } 3\end{array}$ & $\begin{array}{l}\text { Eastern } \\
\text { Mediterranean }\end{array}$ & Othonoi-Greece & $\begin{array}{l}\text { CEAB.POR.G } \\
\text { EN.024 }\end{array}$ & $\begin{array}{l}\text { 18S: } \\
\text { KY002168 } \\
\text { 28S: } \\
\text { KY002195 }\end{array}$ \\
\hline $\begin{array}{l}\text { H. mediterránea } \\
\text { sp. nov. ind. } 4\end{array}$ & $\begin{array}{l}\text { Eastern } \\
\text { Mediterranean }\end{array}$ & Othonoi-Greece & $\begin{array}{l}\text { CEAB.POR.G } \\
\text { EN.025 }\end{array}$ & $\begin{array}{l}\text { 18S: } \\
\text { KY002169 } \\
\text { 28S: } \\
\text { KY002196 }\end{array}$ \\
\hline $\begin{array}{l}\text { Crella cyatophora } \\
\text { ind.1 }\end{array}$ & Red Sea & $\begin{array}{l}\text { Dedalos- } \\
\text { Brother Islands }\end{array}$ & $\begin{array}{l}\text { CEAB.POR.G } \\
\text { EN.026 }\end{array}$ & $\begin{array}{l}\text { COI: } \\
\text { KY002120 } \\
\text { 18S: } \\
\text { KY002173 } \\
\text { 28S: } \\
\text { KY002177 }\end{array}$ \\
\hline $\begin{array}{l}\text { Crella cyatophora } \\
\text { ind. } 2\end{array}$ & Red Sea & $\begin{array}{l}\text { Elphistone- } \\
\text { Brother Islands }\end{array}$ & $\begin{array}{l}\text { CEAB.POR.G } \\
\text { EN.027 }\end{array}$ & $\begin{array}{l}\text { COI: } \\
\text { KY002121 } \\
\text { 18S: } \\
\text { KY002174 } \\
\text { 28S: } \\
\text { KY002178 } \\
\end{array}$ \\
\hline $\begin{array}{l}\text { Crella cyatophora } \\
\text { ind. } 3\end{array}$ & Pacific & $\begin{array}{l}\text { Bempton } \\
\text { Patch Reef } \\
\text { (beween New } \\
\text { Caledonian and } \\
\text { Australia }\end{array}$ & $\begin{array}{l}\text { CEAB.POR.G } \\
\text { EN.028 }\end{array}$ & $\begin{array}{l}\text { COI: } \\
\text { KY002122 } \\
\text { 18S: } \\
\text { KY002175 } \\
\text { 28S: } \\
\text { KY002179 } \\
\end{array}$ \\
\hline
\end{tabular}




\begin{tabular}{|c|c|c|c|c|}
\hline $\begin{array}{l}\text { Crella cyatophora } \\
\text { ind. } 4\end{array}$ & Pacific & $\begin{array}{l}\text { Bempton } \\
\text { Patch Reef } \\
\text { (beween New } \\
\text { Caledonian and } \\
\text { Australia }\end{array}$ & $\begin{array}{l}\text { CEAB.POR.G } \\
\text { EN.029 }\end{array}$ & $\begin{array}{l}\text { COI: } \\
\text { KY002123 } \\
\text { 18S: } \\
\text { KY002176 } \\
\text { 28S: } \\
\text { KY002180 }\end{array}$ \\
\hline Crella elegans & Mediterranean & France & & $\begin{array}{l}\text { 18S: } \\
\text { KC902282 }\end{array}$ \\
\hline Crella elegans & Mediterranean & France & & $\begin{array}{l}18 \mathrm{~S}: \\
\text { AY348882 }\end{array}$ \\
\hline Crella elegans & Mediterranean & France & & $\begin{array}{l}28 \mathrm{~S} \\
\text { HQ393898 }\end{array}$ \\
\hline Crella plana & $\begin{array}{l}\text { Northeastern } \\
\text { Atlantic }\end{array}$ & $\begin{array}{l}\text { Northern } \\
\text { Ireland }\end{array}$ & & $\begin{array}{l}\text { 18S: } \\
\text { KC9023009 }\end{array}$ \\
\hline Crella rosea & $\begin{array}{l}\text { Northeastern } \\
\text { Atlantic }\end{array}$ & $\begin{array}{l}\text { Northern } \\
\text { Ireland }\end{array}$ & & $\begin{array}{l}\text { 28S:HQ37929 } \\
9\end{array}$ \\
\hline Crella rosea & $\begin{array}{l}\text { Northeastern } \\
\text { Atlantic }\end{array}$ & $\begin{array}{l}\text { Northern } \\
\text { Ireland }\end{array}$ & & $\begin{array}{l}\text { 18S:KC90228 } \\
2\end{array}$ \\
\hline Phorbas bihamiger & $\begin{array}{l}\text { Northeastern } \\
\text { Atlantic }\end{array}$ & English Channel & & $\begin{array}{l}\text { 18S: } \\
\text { KC901921.1 } \\
\text { 28S: } \\
\text { KC869431 }\end{array}$ \\
\hline Phorbas punctatus & $\begin{array}{l}\text { Northeastern } \\
\text { Atlantic }\end{array}$ & Wales & & $\begin{array}{l}\text { 18S: } \\
\text { KC869439.1 } \\
\text { 28S: } \\
\text { KC869439.1 }\end{array}$ \\
\hline Phorbas dives & $\begin{array}{l}\text { Northeastern } \\
\text { Atlantic }\end{array}$ & English Channel & & $\begin{array}{l}28 \mathrm{~S}: \mathrm{HQ} 37930 \\
3\end{array}$ \\
\hline Phorbas fictitioides & North Pacific & - & & $\begin{array}{l}\text { COI:HE61161 } \\
7.1\end{array}$ \\
\hline Phorbas tenacior & $\begin{array}{l}\text { Northeastern } \\
\text { Atlantic }\end{array}$ & - & & $\begin{array}{l}\text { 18S: } \\
\text { AY348881 }\end{array}$ \\
\hline Phorbas glaberrimus & Antarctic & Ross Sea & & $\begin{array}{l}\text { COI:LN85021 } \\
6.1\end{array}$ \\
\hline $\begin{array}{l}\text { Hymedesmia } \\
\text { paupertas }\end{array}$ & $\begin{array}{l}\text { Northeastern } \\
\text { Atlantic }\end{array}$ & & & $\begin{array}{l}\text { 18S: } \\
\text { KC902073.1 } \\
\text { 28S: } \\
\text { KF018118.1 }\end{array}$ \\
\hline Hymedesmia pansa & & & & $\begin{array}{l}\text { 18S: } \\
\text { KC902027.1 }\end{array}$ \\
\hline $\begin{array}{l}\text { Hymedesmia } \\
\text { paupertas }\end{array}$ & $\begin{array}{l}\text { Northeastern } \\
\text { Atlantic }\end{array}$ & & & $\begin{array}{l}\text { 28S: } \\
\text { KF018118.1 }\end{array}$ \\
\hline $\begin{array}{l}\text { Kirkpatrickia } \\
\text { variolosa }\end{array}$ & Antarctic & Ross Sea & & $\begin{array}{l}\text { COI: } \\
\text { LN850202.1 }\end{array}$ \\
\hline
\end{tabular}

Table 1. Geographical origin and ecological distribution of the individuals used in the phylogenetic study, with accession numbers. Individuals sequenced de novo are in bold 
Table 2 (on next page)

PCR conditions for the three partitions used (COI, $28 \mathrm{~S}$ and 18S). 
2 Table 2. PCR conditions for the three partitions used (COI, 28S and 18S). 


\section{Table 3(on next page)}

Locality and spicule sizes of the studied individuals, and comparison with descriptions by other authors. 


\begin{tabular}{|c|c|c|c|c|c|c|}
\hline Species & Author & Locality & $\begin{array}{l}\text { Depth }(\mathrm{m}) / \\
\text { assemblage }\end{array}$ & styles & strongyles (range/mean) & acanthoxeas \\
\hline $\begin{array}{l}\text { H. arabica } \\
\text { ind. } 1\end{array}$ & This study & $\begin{array}{l}\text { Red Sea } \\
\text { (Egypt) }\end{array}$ & 14 /coral reef & $\begin{array}{l}160-189(179.6) \times \\
7-8(7.5)\end{array}$ & $\begin{array}{l}210-290(273) \mathrm{x} \\
2.8-4.1(3.6)\end{array}$ & - \\
\hline H. arabica & Illan et al. 2004 & $\begin{array}{l}\text { Red Sea } \\
\text { (Egypt) }\end{array}$ & & $\begin{array}{l}190-250(218) \times \\
3.5-5(4.7)\end{array}$ & $\begin{array}{l}200-290(266) \times \\
2.5-4(3.5)\end{array}$ & - \\
\hline $\begin{array}{l}\text { H. mediterránea } \\
\text { ind. } 7\end{array}$ & This study & $\begin{array}{l}\text { Adriatic } \\
\text { (Croatia) }\end{array}$ & $\begin{array}{l}10-15 / \text { rocky } \\
\text { sub-horizontal }\end{array}$ & 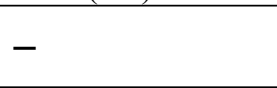 & $\begin{array}{l}233-330(274.8) \times \\
3-4.6(4.0)\end{array}$ & - \\
\hline $\begin{array}{l}\text { H. mediterránea } \\
\text { ind. } 11\end{array}$ & This study & $\begin{array}{l}\text { Adriatic } \\
\text { (Italy) }\end{array}$ & $\begin{array}{l}10-15 / \text { rocky } \\
\text { sub-horizontal }\end{array}$ & - & $\begin{array}{l}251-300(276.6) \times \\
2.1-4(3.0)\end{array}$ & - \\
\hline $\begin{array}{l}\text { H. mediterránea } \\
\text { ind. } 5\end{array}$ & This study & $\begin{array}{l}\text { Adriatic } \\
\text { (Albania) }\end{array}$ & $\begin{array}{l}\text { 10-15/rocky } \\
\text { sub-horizontal }\end{array}$ & - & $\begin{array}{l}274-317(296.4) \mathrm{x} \\
2.9-4.5(4.0)-\end{array}$ & - \\
\hline $\begin{array}{l}\text { H. mediterránea } \\
\text { ind. } 10\end{array}$ & This study & $\begin{array}{l}\text { Central Med. } \\
\text { (Italy) }\end{array}$ & $\begin{array}{l}10-15 / \text { rocky } \\
\text { sub-horizontal. }\end{array}$ & - & $\begin{array}{l}229-328(291.3) \times \\
2.4-5.2(3.5)\end{array}$ & - \\
\hline $\begin{array}{l}\text { H. mediterránea } \\
\text { ind. } 3\end{array}$ & This study & $\begin{array}{l}\text { Eastern Med. } \\
\text { (Greece) }\end{array}$ & $\begin{array}{l}\text { 10-15/rocky } \\
\text { sub-horizontal }\end{array}$ & - & $\begin{array}{l}242-340(272.7) \times \\
2.6-4(3.2)\end{array}$ & - \\
\hline $\begin{array}{l}\text { H. mediterránea } \\
\text { ind. } 1\end{array}$ & This study & $\begin{array}{l}\text { NW Med. } \\
\text { (Spain) }\end{array}$ & 12-16/rocky wall & - & $\begin{array}{l}261-320(296.3) \mathrm{x} \\
3.1-3.8(3.5)\end{array}$ & - \\
\hline $\begin{array}{l}\text { H. columella } \\
\text { ind. } 1\end{array}$ & This study & $\begin{array}{l}\text { NW Med. } \\
\text { (Spain) }\end{array}$ & $27-29 /$ coralligenous & - & $\begin{array}{l}302-435(370) \times \\
3-4(3.7)\end{array}$ & - \\
\hline "H columella" & Vacelet 1987 & $\begin{array}{l}\text { NW Med. } \\
\text { (France) }\end{array}$ & - & - & $\begin{array}{l}225-310(285) \mathrm{x} \\
2-4(3)\end{array}$ & - \\
\hline H. columella & Vacelet 1987 & $\begin{array}{l}\text { NW Med. } \\
\text { (France) }\end{array}$ & - & - & $\begin{array}{l}320-410(369) \mathrm{x} \\
2.5-3.8(3.1)\end{array}$ & - \\
\hline "H. columella" & Vacelet 1987 & $\begin{array}{l}\text { NW Med. } \\
\text { (France) }\end{array}$ & - & - & $\begin{array}{l}220-320(273) \mathrm{x} \\
2-4(2,7)\end{array}$ & - \\
\hline H. columella & Vacelet 1987 & $\begin{array}{l}\text { North Atlantic } \\
\text { (France) }\end{array}$ & - & - & $\begin{array}{l}290-465(394) \times \\
4-7(5.1)\end{array}$ & - \\
\hline H. columella & Topsent 1925 & $\begin{array}{l}\text { North Atlantic } \\
\text { (France) }\end{array}$ & - & - & $400 \times 6$ & - \\
\hline H. columella" & Foster 1995 & $\begin{array}{l}\text { North Atlantic } \\
\text { (UK) }\end{array}$ & - & - & $\begin{array}{l}330-420(373) \times \\
5-6(5.85)\end{array}$ & - \\
\hline H. columella & Bowerbank1874 & $\begin{array}{l}\text { North Atlantic } \\
\text { (UK) }\end{array}$ & - & - & $376 \times 7$ & - \\
\hline $\begin{array}{l}\text { Crella } \\
\text { Cyatophora ind 3 }\end{array}$ & This study & $\begin{array}{l}\text { Indo-Pacific } \\
\text { (Bemptom) }\end{array}$ & $18 \mathrm{~m} /$ coral reef & - & $\begin{array}{l}\text { 205-308 (263.9)x } \\
2.2-4.3(3.4)\end{array}$ & $\begin{array}{l}92-115(105.4) x \\
2-2.3(2)\end{array}$ \\
\hline
\end{tabular}




\begin{tabular}{|l|l|l|l|l|l|l|}
\hline $\begin{array}{l}\text { C. cyatophora } \\
\text { ind 1 }\end{array}$ & This study & $\begin{array}{l}\text { Red Sea } \\
\text { (Egypt) }\end{array}$ & $12 /$ coral reef & - & $\begin{array}{l}227-293(267.8) \mathrm{x} \\
2.5-3.9(3.4)\end{array}$ & $\begin{array}{l}89-120(109.4) \times \\
1.8-2.5(2.47)\end{array}$ \\
\hline
\end{tabular}

Table 3. Locality and spicule sizes of the studied individuals, and comparison with descriptions by other authors. 